\title{
The Biosynthesis of Adrenal Steroids: Effects of Angiotensin II, Adrenocorticotropin, and Potassium *
}

\author{
Norman M. Kaplan $\dagger$ with the technical assistance of Robert Cook \\ (From the Department of Internal Medicine, The University of Texas Southwestern Medical \\ School, Dallas, Texas)
}

The search for the physiologic mechanism controlling the biosynthesis of aldosterone has centered upon three factors-ACTH, the renin-angioten$\sin ^{1}$ system, and potassium. All three have been shown to stimulate the production of aldosterone in the intact animal (1-4). Despite a large number of in vivo experiments involving the rat, dog, sheep, and man, the exact locus of each stimulus within the control mechanism and the precise relationships of one to the other have not been clearly defined. In particular, disagreement persists as to the physiologic role of the renin-angiotensin system $(2,3,5)$.

The initial results of in vitro studies of the effects of ACTH and angiotensin on the biosynthesis of adrenal steroids have been published (6). In those studies, in which the effects upon aldosterone and cortisol were nonselective, relatively large amounts of both agents were used. Additional in vitro experiments have therefore been performed, studying the effects of smaller amounts of these agents as well as potassium, alone and in combination, in an attempt to elucidate further their role in the control of aldosterone biosynthesis.

* Submitted for publication June 28, 1965; accepted September 9, 1965.

Presented in part at the Forty-fifth Annual Meeting of the Endocrine Society, June 13, 1963, and the Fifty-sixth Annual Meeting of the American Society for Clinical Investigation, May 3, 1964.

This work was supported by grants from the Dallas and Texas Heart Associations and the U. S. Public Health Service, National Institute of Arthritis and Metabolic Diseases (AM 06938-03).

† Address requests for reprints to Dr. Norman M. Kaplan, Dept. of Internal Medicine, University of Texas Southwestern Medical School, Dallas, Texas 75235.

1 Unless otherwise stated, the term "angiotensin" is used to designate the active octapeptide, angiotensin II.

\section{Methods}

Tissue preparation and incubation. The studies were carried out with slices of beef adrenal cortex prepared in the manner of the previous study (6). The glands were incubated within 2 hours after death of the animals. Slices were taken with a microtome.

In studies upon aldosterone synthesis alone, only outer slices were incubated, since histologically this slice includes most of the zona glomerulosa. When cortisol synthesis was also studied, the next inner slice was also taken, since it includes considerable zona fasciculata. When only cortisol synthesis was studied, only the third slice was used. The different slices were shown to vary in their initial steroid content by assays of nonincubated slices used in four separate experiments. The mean steroid contents (in $\mu \mathrm{g}$ per $\mathrm{g}$ tissue) were as follows: 1 ) outer slices, aldosterone 3.85 ; corticosterone 3.65 ; cortisol $0.68 ; 2)$ second slices, aldosterone 3.03 ; corticosterone 5.55 ; cortisol $7.80 ; 3$ ) third slices, aldosterone 0.15 ; corticosterone 2.36; cortisol 7.23. The slices used in each experiment were combined and minced to obtain uniformity. At least four vessels containing 400 to $667 \mathrm{mg}$ of tissue were incubated and analyzed separately for each portion of each experiment.

No effect of angiotensin upon this in vitro preparation was observed if the tissues were not first preincubated and the preincubation media replaced with fresh media. Therefore, in all experiments, the tissues were preincubated for 1 hour in Krebs-Ringer bicarbonate medium containing glucose at a concentration of $200 \mathrm{mg}$ per 100 $\mathrm{ml}$. The glucose was omitted in the studies of phosphorylase activity. The preincubation medium was then replaced with $5 \mathrm{ml}$ of fresh medium and the appropriate stimulatory agent added. Each vessel was gassed with $95 \% \mathrm{O}_{2}-5 \% \quad \mathrm{CO}_{2}$ and capped tightly. At least four vessels served as controls in each experiment, and there were from 24 to 44 vessels in the various studies. Incubation was usually for 120 minutes but occasionally for 150 or 180 minutes.

Stimulatory agents. Porcine ACTH-gel, ${ }^{2}$ used in previous studies (6) and shown to be biologically effective on steroidogenesis in man, was used in experiments $1,2,17$, and 20 . In all other studies, porcine, aqueous $\mathrm{ACTH}{ }^{3}$ was used. Angiotensin was synthetic asparaginyl-1, valine-5 angiotensin II, prepared in

\footnotetext{
2 National Drug, Philadelphia, Pa.
}

${ }^{3}$ Upjohn, Kalamazoo, Mich. 
$200-\mu \mathrm{g}$ amounts in vials without preservative and dissolved in saline just before use. 4 Adenosine- $3^{\prime}, 5^{\prime}$-monophosphate $\left(3^{\prime}, 5^{\prime}-\mathrm{AMP}\right)$ was dissolved in Krebs-Ringer bicarbonate medium and brought to $\mathrm{pH} 7.4$ by addition of $1 \mathrm{~N}$ sodium hydroxide. The concentrations of potassium in the media were varied by using more or less potassium chloride. Unless otherwise specified, the potassium concentration of the media was $5.8 \mathrm{mEq}$ per $\mathrm{L}$.

Assay procedures. After incubation, the media were decanted, and from 2 to $5 \mathrm{ml}$ was analyzed for steroids by a double isotope derivative assay (7). The assay technique was not changed except for the addition of known amounts of the appropriate ${ }^{14} \mathrm{C}$-ring-labeled steroids to each sample of medium as internal standards at the onset of the assay instead of after acetylation. Thereby correction was made for any losses of steroid from the very beginning of the assay. Two paper chromatographic separations were used before and one after oxidation of the tritium-labeled acetates of the different steroids.

Phosphorylase activity was assayed in the adrenal tissue after incubation by the technique of Sutherland (8). The potassium concentrations of the incubation medium were determined by flame photometry.

Considerable variation between experiments both in the levels of steroid synthesized in the control vessels and in the effect of various stimuli was noted. Thus, the control levels of aldosterone after 120 -minute incubations varied from 2.63 to $6.90 \mu \mathrm{g}$ per $\mathrm{g}$ tissue. Such variation was noted in previous in vitro studies (6). However, even greater variation than this has been observed during

${ }^{4}$ Kindly supplied by Dr. Jack L. Graeme, Ciba Pharmaceutical Co., Summit, N. J. in vivo studies when the experimental designs should allow for even greater stability of steroid synthesis (1-5). It could be argued that the variation in the degree of stimulation of steroid synthesis in different experiments could reflect variations in the rate of inactivation of the stimulatory agents, but this could not explain the differences in the effects of a stimulatory agent on the various steroids within a single experiment, since the various steroids were all measured in the media from the same vessels. Moreover, in each experiment, an effect of each stimulatory agent was observed on one or more steroids so that complete inactivation was ruled out.

Values are expressed as micrograms of steroid in the incubation medium per gram of tissue per total time of incubation. The mean and standard deviation of the steroid values in each group of vessels were compared to those of the control specimens simultaneously incubated. The per cent increase over the control levels was also determined. Statistical evaluation was by the $t$ test (9).

\section{Results}

These studies were designed to examine three aspects of steroid biosynthesis: first, the separate effects of ACTH, angiotensin, and potassium ; second, the effects of various combinations of these three stimuli; and third, possible differences in the mode of action of ACTH and angiotensin.

The effect of ACTH upon steroid synthesis (Table $I$ ). In six experiments, amounts of

TABLE I

Effects of ACTH upon steroid biosynthesis in beef adrenal tissue*

\begin{tabular}{|c|c|c|c|c|c|c|c|c|c|}
\hline & \multirow{2}{*}{$\begin{array}{c}\text { Experi- } \\
\text { ment } \\
\text { no. }\end{array}$} & \multicolumn{8}{|c|}{ Amount of ACTH ( $\mu \mathrm{g} / \mathrm{g}$ tissue) } \\
\hline & & None & 0.01 & 0.1 & 1.0 & 2.0 & 5.0 & 10.0 & 100.0 \\
\hline \multirow{6}{*}{$\begin{array}{l}\text { Aldosterone, } \\
\mu \mathrm{g} / \mathrm{g} \\
\quad \text { tissue }\end{array}$} & 1 & $3.64 \pm 0.80$ & $3.51 \pm 0.72$ & $4.46 \pm 0.68$ & $5.13 \pm 1.50$ & & & $11.32 \pm 1.94$ & $10.96 \pm 1.80$ \\
\hline & 2 & $5.14 \pm 0.50$ & $5.20 \pm 0.63$ & $5.58 \pm 0.74$ & $5.83 \pm 0.91$ & & $8.65 \pm 1.05$ & $9.66 \pm 1.42$ & \\
\hline & 3 & $2.63 \pm 0.32$ & & $2.51 \pm 0.48$ & $2.95 \pm 0.45$ & $2.88 \pm 0.60$ & & $6.03 \pm 0.82$ & \\
\hline & 4 & $4.20 \pm 1.33$ & & & $4.33 \pm 0.92$ & $4.20 \pm 1.14$ & & $8.11 \pm 1.23$ & \\
\hline & 5 & $4.11 \pm 0.21$ & & & $4.20 \pm 0.52$ & $4.63 \pm 0.08$ & $6.56 \pm 0.87$ & $8.80 \neq 0.98$ & \\
\hline & 6 & $5.70 \pm 0.71$ & & & $5.55 \pm 0.90$ & & $8.97 \pm 0.65$ & & \\
\hline \multicolumn{3}{|c|}{ Mean per cent increase over control } & 0 & $9 \%$ & $11 \%$ & $8 \%$ & $62 \%$ & $126 \%$ & $200 \%$ \\
\hline \multirow{6}{*}{$\begin{array}{l}\text { Corticosterone, } \\
\mu \mathrm{g} / \mathrm{g} \\
\text { tissue }\end{array}$} & 1 & $3.56 \pm 0.50$ & $4.31 \pm 0.40$ & $6.12 \pm 0.78$ & $8.33 \pm 1.33$ & & & $10.56 \pm 1.51$ & $10.78 \pm 1.32$ \\
\hline & 2 & $7.04 \pm 0.88$ & $7.22 \pm 1.10$ & $9.73 \pm 1.11$ & $11.76 \pm 2.44$ & & $14.40 \pm 2.56$ & $14.05 \pm 2.60$ & \\
\hline & 3 & $4.13 \pm 0.44$ & & $5.60 \pm 0.77$ & $7.45 \pm 0.67$ & $9.20 \pm 1.45$ & & $9.88 \pm 1.75$ & \\
\hline & 4 & $1.58 \pm 0.51$ & & & $3.16 \pm 0.90$ & $4.25 \pm 1.30$ & & $4.20 \pm 1.13$ & \\
\hline & 5 & $6.21 \pm 1.11$ & & & $8.04 \pm 1.68$ & $8.25 \pm 2.44$ & $8.16 \pm 1.22$ & $9.07 \pm 2.30$ & \\
\hline & 6 & $6.55 \pm 0.81$ & & & $6.42 \pm 1.03$ & & $6.14 \pm 0.65$ & & \\
\hline \multicolumn{3}{|c|}{ Mean per cent increase over control } & $11 \%$ & $49 \%$ & $68 \%$ & $108 \%$ & $43 \%$ & $130 \%$ & $205 \%$ \\
\hline \multirow{6}{*}{$\begin{array}{l}\text { Cortisol, } \\
\mu g / g \\
\quad \text { tissue }\end{array}$} & 1 & $5.60 \pm 1.12$ & $7.30 \pm 1.58$ & $20.85 \pm 2.40$ & $24.76 \pm 3.02$ & & $\cdot$ & $28.26 \pm 4.58$ & $28.15 \pm 3.62$ \\
\hline & 2 & $5.36 \pm 1.58$ & $6.12 \pm 1.33$ & $18.65 \pm 2.25$ & $23.44 \pm 2.54$ & & $22.67 \pm 3.11$ & $24.51 \pm 3.60$ & \\
\hline & 3 & $8.52 \pm 0.88$ & & $15.02 \pm 1.58$ & $16.51 \pm 1.42$ & $19.60 \pm 1.51$ & & $17.88 \pm 1.34$ & \\
\hline & 4 & $2.92 \pm 1.11$ & & & $12.87 \pm 2.12$ & $14.20 \pm 3.02$ & & $14.30 \pm 2.83$ & \\
\hline & 5 & $2.67 \pm 0.65$ & & & $9.56 \pm 1.76$ & $9.82 \pm 2.22$ & $9.76 \pm 1.69$ & $9.63 \pm 1.46$ & \\
\hline & 6 & $2.84 \pm 0.30$ & & & $8.88 \pm 0.69$ & & $10.78 \pm 0.98$ & & \\
\hline \multicolumn{3}{|c|}{ Mean per cent increase over control } & $22 \%$ & $199 \%$ & $264 \%$ & $261 \%$ & $289 \%$ & $305 \%$ & $404 \%$ \\
\hline
\end{tabular}

* In all of these experiments, outer and second slices were used. 
BIOSYNTHESIS OF ADRENAL STEROIDS

TABLE II

Effects of angiotensin II upon steroid biosynthesis in beef adrenal tissue*

\begin{tabular}{|c|c|c|c|c|c|c|c|}
\hline & \multirow{2}{*}{$\begin{array}{c}\text { Experi- } \\
\text { ment } \\
\text { no. }\end{array}$} & \multicolumn{6}{|c|}{ Amount of angiotensin II ( $\mu \mathrm{g} / \mathrm{g}$ tissue) } \\
\hline & & None & 0.01 & 0.1 & 1.0 & 10.0 & 100.0 \\
\hline $\begin{array}{l}\text { Aldosterone, } \\
\mu g / g \text { tissue }\end{array}$ & $\begin{array}{r}7 \\
8 \\
9 \\
10 \\
11 \\
12 \\
13 \\
14 \\
15 \\
16\end{array}$ & $\begin{array}{l}5.14 \pm 0.50 \\
4.54 \pm 0.78 \\
4.20 \pm 1.33 \\
6.90 \pm 0.74 \\
4.11 \pm 0.21 \\
5.70 \pm 0.71 \\
2.63 \pm 0.32 \\
3.34 \pm 0.62 \\
4.73 \pm 0.58 \\
2.95 \pm 0.36\end{array}$ & $\begin{array}{l}7.02 \pm 1.04 \\
5.48 \pm 0.66 \\
3.40 \pm 0.85\end{array}$ & $\begin{array}{l}5.26 \pm 0.58 \\
4.88 \pm 0.48 \\
4.85 \pm 0.96 \\
9.04 \pm 2.72 \\
6.64 \pm 0.82 \\
9.58 \pm 1.44 \\
4.56 \pm 0.62 \\
5.89 \pm 0.63 \\
8.44 \pm 0.50 \\
6.03 \pm 0.81\end{array}$ & $\begin{array}{r}7.49 \pm 0.64 \\
8.62 \pm 0.90 \\
9.45 \pm 1.10 \\
14.85 \pm 2.65 \\
\\
11.44 \pm 1.63 \\
5.44 \pm 0.59 \\
8.05 \pm 0.93 \\
10.08 \pm 1.16 \\
7.80 \pm 0.78\end{array}$ & $\begin{array}{r}9.15 \pm 1.13 \\
18.28 \pm 3.00 \\
\\
14.16 \pm 2.30 \\
7.33 \pm 1.08\end{array}$ & $\begin{array}{l}10.05 \pm 2.02 \\
18.08 \pm 3.36\end{array}$ \\
\hline \multicolumn{3}{|c|}{ Mean per cent increase over control } & 0 & $52 \%$ & $111 \%$ & $153 \%$ & $147 \%$ \\
\hline $\begin{array}{l}\text { Corticosterone, } \\
\mu g / g \text { tissue }\end{array}$ & $\begin{array}{r}7 \\
8 \\
9 \\
10 \\
11 \\
12 \\
13 \\
14 \\
15 \\
16\end{array}$ & $\begin{array}{l}7.04 \pm 0.88 \\
5.32 \pm 0.69 \\
1.58 \pm 0.51 \\
4.76 \pm 0.56 \\
6.21 \pm 1.11 \\
6.55 \pm 0.81 \\
4.13 \pm 0.44 \\
5.55 \pm 0.80 \\
3.90 \pm 0.46 \\
6.12 \pm 0.76\end{array}$ & $\begin{array}{l}6.02 \pm 1.36 \\
6.96 \pm 0.75 \\
5.38 \pm 0.63\end{array}$ & $\begin{array}{r}12.16 \pm 1.34 \\
5.65 \pm 0.62 \\
4.13 \pm 0.59 \\
6.48 \pm 0.80 \\
10.55 \pm 2.22 \\
6.54 \pm 0.51 \\
5.83 \pm 0.48 \\
8.56 \pm 1.11 \\
2.96 \pm 0.33 \\
5.90 \pm 0.83\end{array}$ & $\begin{array}{r}16.06 \pm 1.94 \\
12.54 \pm 1.67 \\
8.48 \pm 1.13 \\
12.76 \pm 2.85 \\
\\
5.20 \pm 0.44 \\
6.21 \pm 0.94 \\
7.95 \pm 0.80 \\
3.08 \pm 0.56 \\
4.72 \pm 0.71\end{array}$ & $\begin{array}{r}9.90 \pm 1.72 \\
18.80 \pm 3.50 \\
\\
3.58 \pm 0.49 \\
3.03 \pm 0.45\end{array}$ & $\begin{array}{l}26.84 \pm 3.52 \\
18.06 \pm 2.76\end{array}$ \\
\hline \multicolumn{3}{|c|}{ Mean per cent increase over control } & $10 \%$ & $41 \%$ & $95 \%$ & $188 \%$ & $176 \%$ \\
\hline $\begin{array}{l}\text { Cortisol, } \\
\mu g / g \text { tissue }\end{array}$ & $\begin{array}{r}7 \\
8 \\
9 \\
10 \\
11 \\
12 \\
13 \\
14 \\
15 \\
16\end{array}$ & $\begin{array}{l}5.36 \pm 1.58 \\
4.77 \pm 0.57 \\
2.82 \pm 1.11 \\
2.92 \pm 0.92 \\
2.67 \pm 0.65 \\
2.84 \pm 0.30 \\
8.52 \pm 0.88 \\
4.37 \pm 0.60 \\
5.12 \pm 0.35 \\
3.56 \pm 0.46\end{array}$ & $\begin{array}{l}3.02 \pm 0.60 \\
2.91 \pm 0.58 \\
4.35 \pm 0.76\end{array}$ & $\begin{array}{l}7.92 \pm 1.01 \\
4.90 \pm 0.63 \\
3.20 \pm 0.45 \\
3.48 \pm 0.78 \\
3.06 \pm 0.70 \\
3.40 \pm 0.44 \\
8.88 \pm 1.10 \\
4.88 \pm 0.81 \\
6.23 \pm 0.49 \\
3.44 \pm 0.55\end{array}$ & $\begin{array}{r}11.86 \pm 2.52 \\
5.38 \pm 0.77 \\
4.34 \pm 0.72 \\
4.80 \pm 1.98 \\
\\
4.00 \pm 0.58 \\
15.58 \pm 1.60 \\
5.50 \pm 0.50 \\
7.34 \pm 0.81 \\
6.05 \pm 0.88\end{array}$ & $\begin{array}{r}7.64 \pm 1.48 \\
8.74 \pm 2.86 \\
4.14 \pm 0.60 \\
14.78 \pm 3.21\end{array}$ & $\begin{array}{l}12.06 \pm 1.80 \\
19.28 \pm 3.21\end{array}$ \\
\hline Mean per & ent incr & ease over control & $2 \%$ & $15 \%$ & $57 \%$ & $122 \%$ & $255 \%$ \\
\hline
\end{tabular}

* In all experiments, outer and second slices were used.

ACTH varying from $0.01 \mathrm{U}$ to $100 \mathrm{U}$ per $\mathrm{g}$ tissue were added to vessels containing both zona glomerulosa and zona fasciculata. The synthesis of cortisol was markedly stimulated by $0.1 \mathrm{U}$, the synthesis of aldosterone only with $5.0 \mathrm{U}$ or more. The mean per cent increase of aldosterone synthesis in the six experiments with $1.0 \mathrm{U}$ of ACTH was only $11 \%$, whereas cortisol synthesis increased $264 \%$. The synthesis of corticosterone was increased with $0.1 \mathrm{U}$ but to a lesser degree than the synthesis of cortisol. These experiments reveal a high degree of selectivity of the effect of the small doses of ACTH upon the synthesis of cortisol.

The effects of angiotensin upon steroid synthesis (Table II). Similar studies were done with varying doses of angiotensin. Relatively small amounts, 0.1 and $1.0 \mu \mathrm{g}$ per $\mathrm{g}$ tissue, stimulated the synthesis of aldosterone $52 \%$ and $111 \%$, respectively. The synthesis of corticosterone usually increased along with that of aldosterone, but in experiments $12,13,15$, and 16 , the level of corticosterone fell as aldosterone increased.

In all but one of the ten experiments with 0.1 $\mu \mathrm{g}$ angiotensin per $\mathrm{g}$ tissue, the degree of stimulation of aldosterone synthesis was greater than that of cortisol synthesis (Figure 1). In experiments 11 through 16 , the relatively selective effect upon aldosterone was particularly striking. Overall, in the experiments with the $0.1-\mu$ g dose, the difference in the per cent increases of aldosterone synthesis compared to the per cent increases of cortisol synthesis was significantly greater $(\mathrm{p}<0.05)$.

In the nine experiments with $1.0 \mu \mathrm{g}$ angiotensin per $\mathrm{g}$ tissue, the stimulation of aldosterone synthesis was also greater than that of cortisol in all 


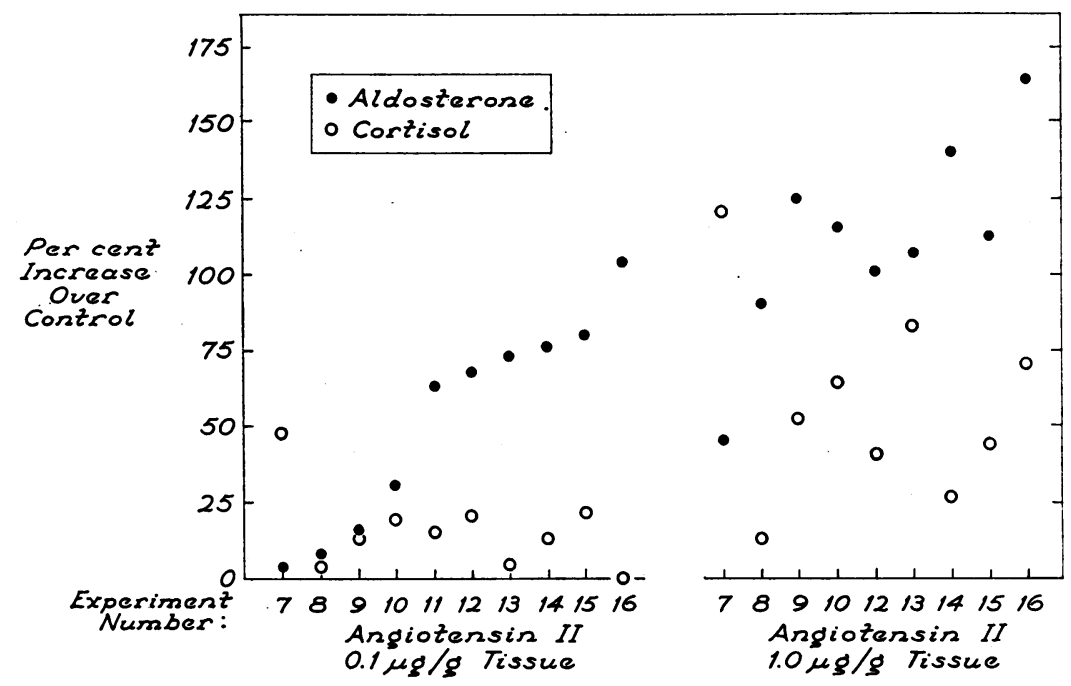

Fig. 1. The effects of ANGIOTENSIN, 0.1 ANd $1.0 \mu$ ger g tissue, UPON THE SYNTHESIS OF ALDOSTERONE AND CORTISOL IN EXPERIMENTS 7 THROUGH 16.

but one. In six of the nine experiments, the effect on aldosterone was more than twofold greater than on cortisol. Taking all experiments with 1.0 $\mu \mathrm{g}$ of angiotensin, the difference in the per cent increase of aldosterone synthesis compared to cortisol synthesis was significant $(\mathrm{p}<0.02)$.
Thus, a relative selectivity of the stimulation of aldosterone synthesis in vitro by angiotensin was found, similar to but less marked than that of cortisol synthesis by ACTH.

The effects of ACTH plus angiotensin upon steroid synthesis (Table III). Studies were next

TABLE III

The effects of ACTH· plus angiotensin upon steroid biosynthesis in beef adrenal tissue

\begin{tabular}{|c|c|c|c|c|c|c|c|}
\hline \multirow{2}{*}{$\begin{array}{l}\text { Experi- } \\
\text { ment } \\
\text { no.* }\end{array}$} & \multirow[b]{2}{*}{ Slices used } & \multicolumn{2}{|c|}{ Stimulant } & \multicolumn{2}{|c|}{ Aldosterone } & \multicolumn{2}{|c|}{ Corticosterone } \\
\hline & & Name & Dose & Mean & SD & Mean & SD \\
\hline \multirow{6}{*}{17} & \multirow{5}{*}{$\begin{array}{l}\text { Outer } \\
\text { and } \\
\text { second }\end{array}$} & & /g tissue & \multicolumn{2}{|c|}{$\mu \mathrm{g} / \mathrm{g}$ tissue } & \multicolumn{2}{|c|}{$\mu \mathrm{g} / \mathrm{g}$ tissue } \\
\hline & & None & & 5.14 & 0.50 & 7.04 & 0.88 \\
\hline & & ACTH & I U & 5.83 & 0.91 & 11.76 & 2.44 \\
\hline & & Angiotensin & $1 \mu \mathrm{g}$ & 7.49 & 0.64 & 16.06 & 1.94 \\
\hline & & $\begin{array}{l}\text { ACTH } \\
\text { Angiotensin }\end{array}$ & $\begin{array}{l}\text { I } \mathrm{U}_{\mu \mathrm{and}} \\
1 \mu \mathrm{g}\end{array}$ & 9.94 & 1.45 & 26.04 & 3.13 \\
\hline & - & Angiotensin & $100 \mu \mathrm{g}$ & 10.05 & 2.02 & 26.84 & 3.52 \\
\hline \multirow[t]{5}{*}{18} & \multirow[t]{5}{*}{ Outer } & None & & 4.13 & 0.38 & 5.01 & 0.61 \\
\hline & & ACTH & I U & 3.49 & 0.48 & 11.25 & 1.43 \\
\hline & & Angiotensin & $1 \mu \mathrm{g}$ & 7.52 & 0.51 & 8.00 & 1.46 \\
\hline & & $\begin{array}{l}\text { ACTH } \\
\text { Angiotensin }\end{array}$ & $\begin{array}{l}\text { I U and } \\
1 \mu \mathrm{g}\end{array}$ & 10.76 & 0.81 & 19.30 & 2.54 \\
\hline & & Angiotensin & $100 \mu \mathrm{g}$ & 11.11 & 0.90 & 19.06 & 2.25 \\
\hline \multirow[t]{5}{*}{19} & \multirow{5}{*}{$\begin{array}{l}\text { Outer } \\
\text { and } \\
\text { second }\end{array}$} & None & & 2.63 & 0.32 & 4.13 & 0.44 \\
\hline & & ACTH & I U & 2.95 & 0.45 & 7.45 & 0.67 \\
\hline & & Angiotensin & $1 \mu \mathrm{g}$ & 5.44 & 0.59 & 6.21 & 0.94 \\
\hline & & $\begin{array}{l}\text { ACTH } \\
\text { Angiotensin }\end{array}$ & $\begin{array}{l}\text { I } U \text { and } \\
1 \mu \mathrm{g}\end{array}$ & 7.15 & 0.86 & 7.56 & 0.73 \\
\hline & & Angiotensin & $100 \mu \mathrm{g}$ & 7.42 & 1.26 & 3.15 & 0.57 \\
\hline
\end{tabular}

* The length of incubation was 180 minutes in experiment 17 and 120 minutes in experiments 18 and 19. 
TABLE IV

The effects of $A C T H, 3^{\prime}, 5^{\prime}-A M P$, and angiotensin upon steroid biosynthesis in beef adrenal tissue*

\begin{tabular}{|c|c|c|c|c|c|c|c|}
\hline \multirow{2}{*}{$\begin{array}{c}\text { Experi- } \\
\text { ment } \\
\text { no.t }\end{array}$} & \multirow{2}{*}{$\begin{array}{l}\text { Slices } \\
\text { used }\end{array}$} & \multicolumn{2}{|c|}{ Stimulant } & \multicolumn{2}{|c|}{ Aldosterone } & \multicolumn{2}{|c|}{ Corticosterone } \\
\hline & & Name & Dose & Mean & SD & Mean & SD \\
\hline \multirow{8}{*}{20} & \multirow{8}{*}{ Outer } & & Ig tissue & \multicolumn{2}{|c|}{$\mu g / g$ tissue } & \multicolumn{2}{|c|}{$\mu g / g$ tissue } \\
\hline & & None & & 2.85 & 0.45 & 2.04 & 0.60 \\
\hline & & ACTH & $8 \mathrm{U}$ & 4.11 & 1.53 & 3.16 & 0.95 \\
\hline & & $3^{\prime}, 5^{\prime}$-AMP & $228 \mu$ moles & 7.23 & 1.02 & 6.27 & 1.26 \\
\hline & & Angiotensin & $30 \mu \mathrm{g}$ & 9.42 & 1.02 & 6.87 & 1.83 \\
\hline & & $\begin{array}{l}\text { ACTH } \\
3^{\prime}, 5^{\prime}-A M P\end{array}$ & $\begin{array}{l}8 \mathrm{U} \text { and } \\
228 \mu \text { moles }\end{array}$ & 6.12 & 1.28 & 6.84 & 0.92 \\
\hline & & $\begin{array}{l}\text { ACTH } \\
\text { Angiotensin }\end{array}$ & $\begin{array}{l}8 \mathrm{U} \text { and } \\
30 \mu \mathrm{g}\end{array}$ & 11.37 & 1.45 & 11.79 & 2.58 \\
\hline & & $\begin{array}{l}3^{\prime}, 5^{\prime} \text {-AMP } \\
\text { Angiotensin }\end{array}$ & $\begin{array}{l}228 \mu \text { moles and } \\
30 \mu \mathrm{g}\end{array}$ & 12.99 & 2.32 & 22.89 & 3.16 \\
\hline \multirow[t]{7}{*}{21} & Outer & None & & 4.58 & 0.45 & & \\
\hline & & АCTH & $4 \mathrm{U}$ & 5.55 & 0.86 & & \\
\hline & & $3^{\prime}, 5^{\prime}-\mathrm{AMP}$ & $120 \mu$ moles & 7.27 & 1.22 & & \\
\hline & & Angiotensin & $20 \mu \mathrm{g}$ & 8.30 & 0.78 & & \\
\hline & & $\begin{array}{l}\text { ACTH } \\
3^{\prime}, 5^{\prime}-A M P\end{array}$ & $\begin{array}{l}4 \mathrm{U} \text { and } \\
120 \mu \text { moles }\end{array}$ & 7.20 & 1.44 & & \\
\hline & & $\begin{array}{l}\text { ACTH } \\
\text { Angiotensin }\end{array}$ & $\begin{array}{l}4 \mathrm{U} \text { and } \\
20 \mu \mathrm{g}\end{array}$ & 9.04 & 1.61 & & \\
\hline & & $\begin{array}{l}3^{\prime}, 5^{\prime} \text {-AMP } \\
\text { Angiotensin }\end{array}$ & $\begin{array}{l}120 \mu \text { moles and } \\
20 \mu \mathrm{g}\end{array}$ & 10.85 & 2.00 & & \\
\hline
\end{tabular}

* 3', 5'-AMP $=$ adenosine- $3^{\prime}, 5^{\prime}$-monophosphate.

$\dagger$ The length of incubation was 150 minutes in experiment 20 and 120 minutes in experiment 21.

performed to assess the effect of the combination of ACTH and angiotensin upon steroid synthesis in vitro. One $\mathrm{U}$ of $\mathrm{ACTH}$, which itself had no effect upon the synthesis of aldosterone, was found to potentiate the effect of $1 \mu \mathrm{g}$ of angiotensin. With $1 \mu \mathrm{g}$ of angiotensin, the small amount of ACTH increased the level of aldosterone synthesis to about that reached with $100 \mu \mathrm{g}$ of angiotensin. The synthesis of corticosterone was potentiated by ACTH to an even greater degree than the synthesis of aldosterone in experiments 17 and 18 .

The effect of $3^{\prime}, 5^{\prime}-A M P$ with $A C T H$ and angiotensin (Table $I V$ ). In view of the differences in the selectivity of ACTH and angiotensin and the observed potentiation of the action of angiotensin by ACTH, studies were performed with $3^{\prime}, 5^{\prime}$ AMP, which is thought to be an intermediate in the action of ACTH upon adrenal steroid biosynthesis (10).

Both ACTH and 3',5' AMP had an additive effect to that of angiotensin but not to each other. In experiments 20 and 21, 3',5'-AMP alone significantly stimulated the synthesis of aldosterone, whereas ACTH alone did not. The addition of ACTH to $3^{\prime}, 5^{\prime}$-AMP did not increase steroid levels beyond those reached with $3^{\prime}, 5^{\prime}$-AMP alone. However, each did potentiate the effect of angiotensin. The additive effect of $3^{\prime}, 5^{\prime}$-AMP was greater than that of ACTH.

These results are in keeping with an action of ACTH through $3^{\prime}, 5^{\prime}-\mathrm{AMP}$, whereas they suggest that angiotensin may not act in the same manner.

The effects of ACTH and angiotensin upon phosphorylase activity. According to the proposed mechanism of action of ACTH through $3^{\prime}, 5^{\prime}$ AMP, the activity of the phosphorylase enzyme within the adrenal tissue is thought to be stimulated. If, as the previous experiments suggest, angiotensin does not act in the same manner, it may have no effect upon phosphorylase activity. Studies were then performed with both ACTH and angiotensin, measuring steroid synthesis as well as phosphorylase activity.

In experiment 22, the effects of angiotensin ( 50 $\mu \mathrm{g}$ per $\mathrm{g}$ tissue) and ACTH ( $5 \mathrm{U}$ per $\mathrm{g}$ tissue) were determined upon the synthesis of aldosterone 


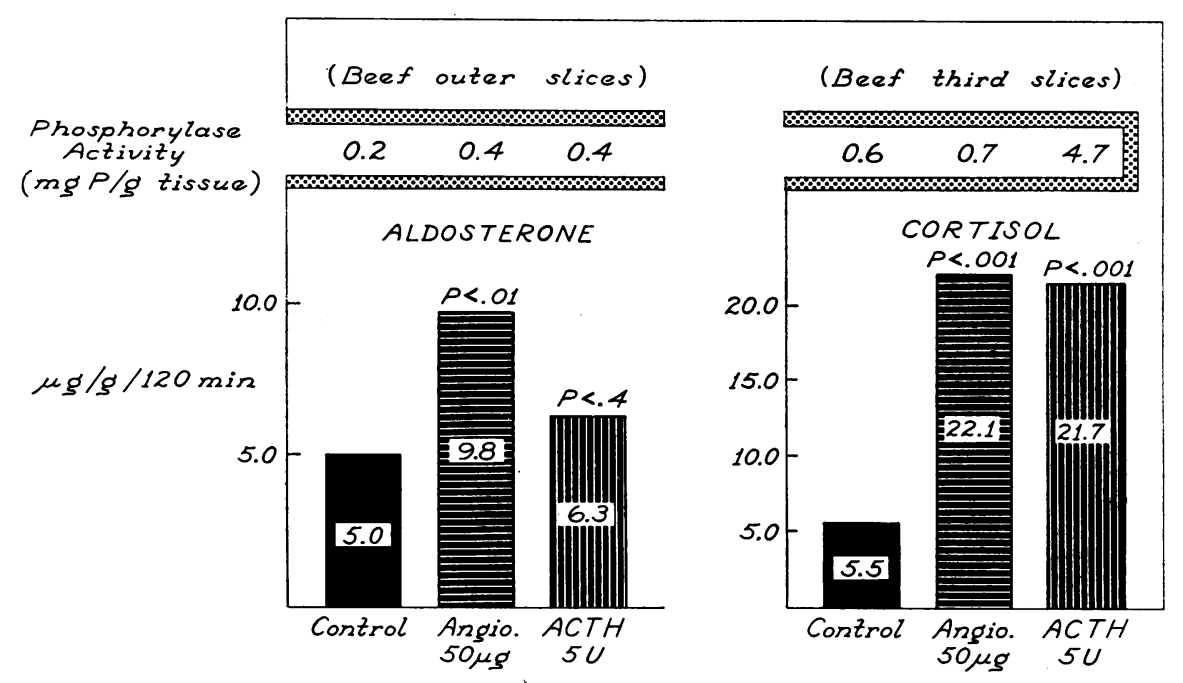

Fig. 2. The EFFects of ANGIOTENSIN AND ACTH UPON ALDOSTERONE SYNTHESIS IN THE OUTER SLICES, UPON CORTISOL SYNTHESIS IN THE THIRD SLICES, AND UPON PHOSPHORYLASE ACTIVITY IN BOTH SLICES OF BEEF ADRENAL GLANDS (EXPERIMENT 22).

and cortisol in the media and upon the activity of phosphorylase in the tissue (Figure 2). As reported by Williams, Johnson, and Field (11), angiotensin did not stimulate the activity of phosphorylase in either outer or third slices at a time that it did stimulate the synthesis of both aldos- terone and cortisol. Similar results were obtained in two other experiments, using $10 \mu \mathrm{g}$ of angiotensin and $2 \mathrm{U}$ of ACTH. ACTH had no effect upon the outer slices, but stimulated both phosphorylase activity and cortisol synthesis in the third slice.

TABLE $\mathrm{V}$

The effects of potassium upon steroid biosynthesis in beef adrenal tissue

\begin{tabular}{|c|c|c|c|c|c|c|c|c|}
\hline \multirow{2}{*}{$\begin{array}{l}\text { Experi- } \\
\text { ment } \\
\text { no.* }\end{array}$} & \multirow[b]{2}{*}{ Slices used } & \multirow{2}{*}{$\begin{array}{c}\text { Potassium } \\
\text { concentration }\end{array}$} & \multicolumn{2}{|c|}{ Aldosterone } & \multicolumn{2}{|c|}{ Corticosterone } & \multicolumn{2}{|c|}{ Cortisol } \\
\hline & & & Mean & SD & Mean & SD & Mean & $\mathrm{SD}$ \\
\hline 23 & Outer & $\begin{array}{r}m E q / L \\
1.5 \\
4.0 \\
5.9 \\
9.8 \\
11.0\end{array}$ & $\begin{array}{l}\mu g / g \\
2.54 \\
3.17 \\
5.46 \\
7.18 \\
8.00\end{array}$ & $\begin{array}{l}u e \\
0.33 \\
0.40 \\
0.60 \\
0.48 \\
0.54\end{array}$ & $\begin{array}{c}\mu g / g \\
2.69 \\
5.92 \\
7.38 \\
12.84 \\
12.99\end{array}$ & $\begin{array}{l}u e \\
0.21 \\
0.43 \\
0.36 \\
1.00 \\
1.44\end{array}$ & $\mu g / g$ & \\
\hline 24 & $\begin{array}{l}\text { Outer } \\
\text { and } \\
\text { second }\end{array}$ & $\begin{array}{r}5.8 \\
11.6\end{array}$ & $\begin{array}{l}2.63 \\
5.14\end{array}$ & $\begin{array}{l}0.32 \\
0.68\end{array}$ & $\begin{array}{l}4.13 \\
4.53\end{array}$ & $\begin{array}{l}0.44 \\
0.41\end{array}$ & $\begin{array}{r}8.52 \\
10.30\end{array}$ & $\begin{array}{l}0.88 \\
2.02\end{array}$ \\
\hline 25 & $\begin{array}{l}\text { Outer } \\
\text { and } \\
\text { second }\end{array}$ & $\begin{array}{c}0 \\
5.8 \\
11.4\end{array}$ & $\begin{array}{r}4.23 \\
5.70 \\
10.77\end{array}$ & $\begin{array}{l}0.45 \\
0.71 \\
1.14\end{array}$ & $\begin{array}{l}3.40 \\
6.55 \\
8.15\end{array}$ & $\begin{array}{l}0.41 \\
0.81 \\
0.40\end{array}$ & $\begin{array}{l}2.44 \\
2.84 \\
3.47\end{array}$ & $\begin{array}{l}0.50 \\
0.30 \\
0.58\end{array}$ \\
\hline 26 & $\begin{array}{l}\text { Outer } \\
\text { and } \\
\text { second }\end{array}$ & $\begin{array}{r}4.9 \\
5.8 \\
12.2\end{array}$ & $\begin{array}{l}4.25 \\
4.48 \\
9.13\end{array}$ & $\begin{array}{l}0.63 \\
0.41 \\
0.74\end{array}$ & & & $\begin{array}{r}8.77 \\
9.33 \\
10.60\end{array}$ & $\begin{array}{l}1.16 \\
1.23 \\
0.91\end{array}$ \\
\hline 27 & Outer & $\begin{array}{r}4.8 \\
5.9 \\
10.4\end{array}$ & $\begin{array}{r}4.60 \\
5.13 \\
10.54\end{array}$ & $\begin{array}{l}0.46 \\
0.38 \\
0.92\end{array}$ & $\begin{array}{r}4.22 \\
5.01 \\
13.22\end{array}$ & $\begin{array}{l}0.59 \\
0.61 \\
1.11\end{array}$ & & \\
\hline 28 & $\begin{array}{l}\text { Outer } \\
\text { and } \\
\text { second }\end{array}$ & $\begin{array}{r}5.8 \\
8.7 \\
11.6 \\
14.5\end{array}$ & $\begin{array}{l}3.16 \\
6.02 \\
8.43 \\
9.12\end{array}$ & $\begin{array}{l}0.41 \\
0.75 \\
0.65 \\
1.02\end{array}$ & $\begin{array}{r}3.79 \\
7.15 \\
8.20 \\
11.18\end{array}$ & $\begin{array}{l}0.52 \\
0.93 \\
0.86 \\
1.62\end{array}$ & $\begin{array}{l}5.14 \\
5.26 \\
5.44 \\
5.45\end{array}$ & $\begin{array}{l}0.82 \\
0.63 \\
0.80 \\
0.55\end{array}$ \\
\hline
\end{tabular}

* The length of incubation was 120 minutes in all experiments. 
BIOSYNTHESIS OF ADRENAL STEROIDS

TABLE VI

The effects of potassium plus angiotensin upon steroid biosynthesis in beef adrenal tissue

\begin{tabular}{|c|c|c|c|c|c|c|c|}
\hline \multirow{2}{*}{$\begin{array}{c}\text { Experi- } \\
\text { ment } \\
\text { no.* }\end{array}$} & \multirow[b]{2}{*}{ Slices used } & \multirow{2}{*}{$\begin{array}{c}\text { Potassium } \\
\text { concentration }\end{array}$} & \multirow{2}{*}{$\begin{array}{c}\text { Dose of } \\
\text { angiotensin }\end{array}$} & \multicolumn{2}{|c|}{ Aldosterone } & \multicolumn{2}{|c|}{ Corticosterone } \\
\hline & & & & Mean & $\mathrm{SD}$ & Mean & $\mathrm{SD}$ \\
\hline \multirow{5}{*}{29} & \multirow{5}{*}{$\begin{array}{l}\text { Outer } \\
\text { and } \\
\text { second }\end{array}$} & $m E q / L$ & \multirow{5}{*}{$\begin{array}{l}\text { /g tissue } \\
\text { None } \\
1.0 \mu \mathrm{g} \\
\text { None } \\
1.0 \mu \mathrm{g} \\
\text { None } \\
1.0 \mu \mathrm{g}\end{array}$} & \multicolumn{2}{|c|}{$\mu g / g$ tissue } & \multicolumn{2}{|c|}{$\mu \mathrm{g} / \mathrm{g}$ tissue } \\
\hline & & 4.9 & & 4.25 & 0.63 & & \\
\hline & & & & 6.16 & 0.70 & & \\
\hline & & 5.8 & & $\begin{array}{l}4.48 \\
9.70\end{array}$ & $\begin{array}{l}0.41 \\
0.99\end{array}$ & & \\
\hline & & 12.2 & & $\begin{array}{r}9.13 \\
12.34\end{array}$ & $\begin{array}{l}0.74 \\
1.62\end{array}$ & & \\
\hline \multirow{6}{*}{30} & \multirow{6}{*}{ Outer } & 4.8 & \multirow{6}{*}{$\begin{array}{l}\text { None } \\
1.0 \mu g \\
\text { None } \\
1.0 \mu g \\
\text { None } \\
1.0 \mu g\end{array}$} & \multirow{6}{*}{$\begin{array}{r}4.60 \\
5.21 \\
5.13 \\
7.52 \\
10.54 \\
12.40\end{array}$} & 0.46 & \multirow{6}{*}{$\begin{array}{r}4.22 \\
5.93 \\
5.01 \\
8.00 \\
13.22 \\
25.86\end{array}$} & 0.59 \\
\hline & & & & & 0.50 & & 0.41 \\
\hline & & 5.9 & & & 0.38 & & 0.61 \\
\hline & & & & & 0.51 & & 1.46 \\
\hline & & 10.4 & & & 0.92 & & 1.11 \\
\hline & & & & & 1.67 & & 3.18 \\
\hline \multirow[t]{9}{*}{31} & \multirow[t]{9}{*}{ Outer } & 1.5 & \multirow{9}{*}{$\begin{array}{l}\text { None } \\
1.0 \mu \mathrm{g} \\
\text { None } \\
1.0 \mu \mathrm{g} \\
\text { None } \\
1.0 \mu \mathrm{g} \\
\text { None } \\
1.0 \mu \mathrm{g} \\
\text { None } \\
1.0 \mu \mathrm{g}\end{array}$} & \multirow{9}{*}{$\begin{array}{r}2.54 \\
4.95 \\
3.17 \\
7.90 \\
5.46 \\
7.50 \\
7.18 \\
10.59 \\
8.00 \\
13.57\end{array}$} & 0.33 & 2.69 & 0.21 \\
\hline & & & & & 0.15 & 3.00 & 0.36 \\
\hline & & 4.0 & & & 0.40 & 5.92 & 0.43 \\
\hline & & & & & 0.88 & 4.56 & 0.61 \\
\hline & & 5.9 & & & $\begin{array}{l}0.60 \\
0.59\end{array}$ & $\begin{array}{l}7.38 \\
7.44\end{array}$ & $\begin{array}{l}0.36 \\
0.58\end{array}$ \\
\hline & & 9.8 & & & 0.48 & 12.84 & $\begin{array}{l}0.00 \\
1.00\end{array}$ \\
\hline & & & & & 1.33 & 8.42 & 0.86 \\
\hline & & 11.0 & & & 0.54 & 12.99 & 1.44 \\
\hline & & & & & 1.67 & 7.49 & 0.62 \\
\hline
\end{tabular}

* The length of incubation was 120 minutes in all experiments.

The effects of potassium upon steroid synthesis $($ Table $V)$. Another stimulus to the secretion of aldosterone in vivo is potassium $(1,12)$. The effect of varying concentrations of potassium upon steroid synthesis in this in vitro preparation was examined. In experiment 23 , as the concentration of potassium in the media was increased from 1.5 to $11.0 \mathrm{mEq}$ per $\mathrm{L}$, the synthesis of aldosterone and corticosterone progressively increased. The synthesis of both was increased significantly only by rather large increases in potassium concentration. With increases of $0.9 \mathrm{mEq}$ per $\mathrm{L}$ (experiment 26) and $1.1 \mathrm{mEq}$ per $\mathrm{L}$ (experiment 27), only slight increases in aldosterone synthesis occurred. No significant change in the level of cortisol synthesis occurred with any change in the concentration of potassium. These experiments demonstrate a selective effect of potassium upon the synthesis of aldosterone and corticosterone in vitro.

The effects of potassium plus angiotensin upon steroid synthesis (Table VI). In view of the potentiation of the action of angiotensin upon aldosterone synthesis by small amounts of ACTH, the effect of small increments of the concentration of potassium was studied.
In experiment 29 , increasing the concentration of potassium from 4.9 to $5.8 \mathrm{mEq}$ per $\mathrm{L}$ had no effect upon the synthesis of aldosterone. However, in the vessels with the higher concentration of potassium, $1.0 \mu \mathrm{g}$ of angiotensin had a significantly greater stimulatory effect upon aldosterone synthesis $(p<0.001)$. Similarly, in experiment 30 , $1.0 \mu \mathrm{g}$ of angiotensin had a greater effect upon the synthesis of aldosterone and corticosterone in the presence of $5.9 \mathrm{mEq}$ per $\mathrm{L}$ of potassium than in the presence of $4.8 \mathrm{mEq}$ per $\mathrm{L}$ of potassium ( $\mathrm{p}<$ 0.001 ).

In both of those experiments and in experiment 31 , angiotensin, $1.0 \mu \mathrm{g}$ per $\mathrm{g}$ tissue, increased the synthesis of aldosterone at all concentrations of potassium. Even at the highest potassium levels, varying from 10.4 to $12.2 \mathrm{mEq}$ per $\mathrm{L}$, angiotensin remained effective.

During experiment 31 , the level of aldosterone synthesis progressively rose in the presence of angiotensin and increasing concentrations of potassium (Figure 3). However, the level of corticosterone synthesis did not progressively increase and actually fell in the vessels with the highest level of aldosterone, those with 9.8 and $11.0 \mathrm{mEq}$ per $\mathrm{L}$ of potassium. 

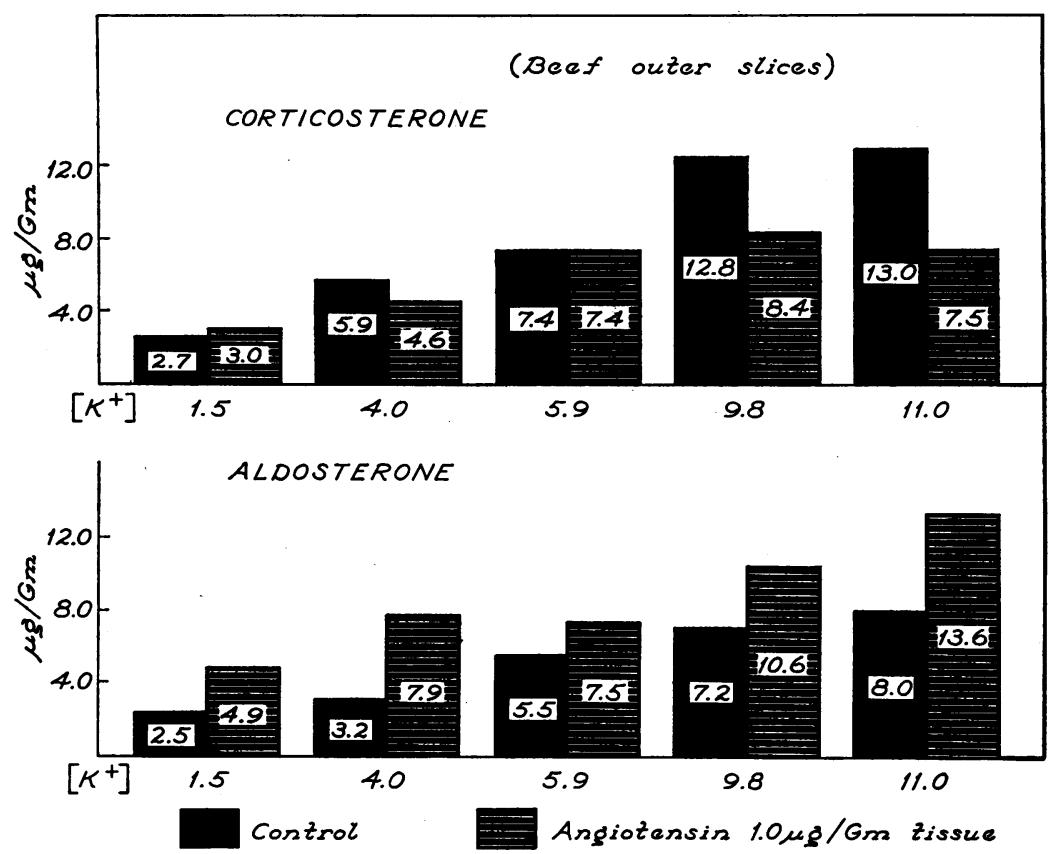

Fig. 3. The effects of varying concentrations of potassium alone (SOLID BARS) AND WITH ANGIOTENSIN (SHADED BARS) UPON THE SYNTHESIS OF CORTICOSTERONE AND ALDOSTERONE BY THE OUTER SLICES OF BEEF ADRENAL GLANDS (EXPERIMENT 31). The concentration of potassium is shown in milliequivalents per liter.

These experiments reveal a potentiation of the effect of angiotensin upon aldosterone synthesis by potassium in concentrations that do not themselves significantly stimulate steroid synthesis.

\section{Discussion}

This study was designed to examine certain aspects of steroid biosynthesis in an in vitro preparation. The results reveal a relative selectivity of the stimulatory effects of ACTH upon cortisol synthesis and of angiotensin and potassium upon aldosterone and corticosterone synthesis. In amounts that in themselves were too small to stimulate steroid synthesis, both ACTH and potassium potentiated the effect of angiotensin upon aldosterone synthesis. In an attempt to elucidate its mechanism of action, angiotensin was found to differ from ACTH in not causing demonstrable increases in phosphorylase activity and in remaining active in the presence of an effect of $3^{\prime}, 5^{\prime}$ AMP.

These results give support to currently held concepts of the control of steroid biosynthesis based on in vivo experiments. These concepts de- fine a primary role of ACTH in the control of cortisol synthesis and of angiotensin in the control of aldosterone synthesis. Recently, attention has mainly centered upon the role of the renin-angiotensin system. According to the hypothesis proposed by Gross (13) and Tobian (14), the juxtaglomerular apparatus secretes renin in response to a decrease in the pulse pressure within the renal afferent arterioles. Renin releases from a substrate the decapeptide, angiotensin I. This is converted to the octapeptide, angiotensin II, which stimulates the secretion of aldosterone.

There is no doubt that angiotensin can stimulate the secretion of aldosterone. The question remains, however, whether angiotensin is the important physiologic stimulus for the secretion of aldosterone. If it is, it should produce a selective stimulation of aldosterone secretion, since the usual physiologic changes that stimulate aldosterone do not stimulate cortisol $(15,16)$. Such a selective stimulation with angiotensin has been shown by some $(2-4,17,18)$ but not by others (5). In addition, the removal of the renin-angiotensin mechanism, i.e., bilateral nephrectomy, 
should prevent the expected increases of aldosterone secretion with physiologic stimuli. Here again, some have shown this to occur in dogs $(18$, 19), whereas others find that removal of the renin-angiotensin mechanism does not prevent stimulation of aldosterone in response to bleeding in rats (20) or continuation of secretion of aldosterone for up to 7 hours in response to severe salt deprivation in sheep (16). The studies on the rat, however, cannot be taken as evidence against the role of the renin-angiotensin system in other species in view of the more recent reports showing that the renin-angiotensin system does not exert an effect upon aldosterone synthesis in the rat (21-23).

On the other hand, ACTH does not appear to be necessary for the secretion of aldosterone, but is the physiologic stimulus for the secretion of cortisol. It does, in large doses, increase aldosterone secretion in vivo (15), but it appears to play a secondary role in supporting the level of steroidogenesis rather than a primary role in initiating steroidogenesis in response to physiologic stimuli (24). The possible role of other humoral substances, including those of pineal origin, remains unsettled, but there is little evidence for their physiologic importance $(4,25)$.

Changes in the concentration of potassium have been found to influence the secretion of aldosterone in vivo, high levels causing stimulation, low levels depression $(1,12)$. These changes occur in the absence of alterations in plasma volume (1), in the isolated adrenal (4) and in the hypophysectomized nephrectomized dog (26). Potassium thus appears to act independently of the other physiologic mechanism for the control of aldosterone synthesis.

The results of these in vitro studies suggest that the renin-angiotensin mechanism is a prime physiologic stimulus to aldosterone synthesis, that ACTH is purely supportive, and that potassium exerts a separate influence. In vitro studies cannot define the role of physiologic control mechanisms, but can indicate their existence and suggest their relative importance. Therefore, the demonstration that angiotensin can stimulate the synthesis of aldosterone in a relatively selective manner supports, but certainly does not prove, the view that angiotensin may be the aldosterone stimulating hormone.
The effects of ACTH upon aldosterone synthesis in vitro provide additional evidence for its secondary, supportive role. In amounts adequate to stimulate markedly the synthesis of cortisol, ACTH did not stimulate the synthesis of aldosterone; amounts of ACTH too little to affect aldosterone synthesis did potentiate the effects of angiotensin.

Increasing concentrations of potassium stimulated the synthesis of aldosterone and corticosterone without significantly affecting cortisol. The changes in potassium concentration required to produce this stimulation were rather large, but smaller changes, in themselves without effect, did potentiate the stimulation by angiotensin.

Although the findings noted in these in vitro studies are in keeping with the results obtained by others in intact animals, certain limitations of in vitro experiments should be considered. First, relatively large amounts of the stimulatory agents were required, amounts quite outside the in vivo "physiologic range." The need for these large amounts has been observed by others using other in vitro systems (27).

Second, the degree of effect of the stimulatory agents as well as the control level of steroid synthesis varied considerably between experiments. Variations in the rate of inactivation of the stimulatory agents within the tissue preparation could explain some of the differences observed between separate experiments. Such variations in inactivation could not, however, explain differences in the effects of a stimulatory agent on the various steroids within a single experiment, since the various steroids were all measured in the media from the same vessels. Moreover, in each experiment, some effect of each stimulatory agent was observed, so complete inactivation was ruled out.

Third, in intact animals the interplay of various feedback systems must be taken into account in examining the selective role of these stimuli. The stimulation of aldosterone secretion by ACTH in vivo persists for only a short time (15); thereafter, an expanded plasma volume may lead to a suppression of the renin-angiotensin mechanism and a fall of aldosterone secretion. Angiotensin will stimulate corticosteroid secretion in vivo, but it appears that the negative corticosteroid feedback mechanism then inhibits ACTH release and thereby leads to a fall in corticosteroid secre- 
tion despite persistence of increased aldosterone secretion (2).

These studies may provide some evidence for the mechanism by which angiotensin stimulates the synthesis of adrenal steroids. First, they suggest that angiotensin acts in a manner different from ACTH. The currently favored hypothesis for the mechanism of the action of ACTH upon steroid synthesis, proposed by Haynes (10), involves an increase in $3^{\prime}, 5^{\prime}$-AMP that activates phosphorylase and thereby provides additional TPNH required in steroidogenesis. The mechanism by which $3^{\prime}, 5^{\prime}$-AMP increases phosphorylase activity apparently involves a decrease in the inactivation of phosphorylase (28). The findings that ACTH increased phosphorylase activity when it stimulated steroid synthesis and did not stimulate steroid synthesis in the presence of presumably maximal effects of added $3^{\prime}, 5^{\prime}$-AMP are in keeping with this scheme. On the other hand, angiotensin does not appear to act by this mechanism, since it did not increase phosphorylase activity when it did stimulate steroid synthesis and an effect of angiotensin was noted in the presence of presumably maximal effects of added ACTH or $3^{\prime}, 5^{\prime}-$ AMP.

Second, these studies suggest that angiotensin stimulates steroid synthesis relatively early in the biosynthetic pathway, before the conversion of corticosterone to aldosterone. In most experiments the synthesis of corticosterone was increased along with that of aldosterone. In some experiments, however, the levels of corticosterone were unchanged or fell while aldosterone increased. Since corticosterone is probably an intermediate in the biosynthetic pathway to aldosterone, it may have been more completely utilized in those tissues most active in steroidogenesis. In the slices used in those experiments, a smaller supply of steroid precursors or a smaller amount of zona fasciculata, wherein the synthesis of corticosterone but not of aldosterone may occur, could also explain these differences. Since angiotensin in large doses will also stimulate the synthesis of cortisol, its site of action may be before the hydroxylation of progesterone. The previous study upon beef adrenal tissue supported an effect at the level of the utilization of cholesterol (6).

The question remains as to why angiotensin and $\mathrm{ACTH}$ in small amounts selectively stimulate the synthesis of aldosterone and cortisol, respectively, whereas in large amounts the synthesis of both steroids is stimulated. One possible explanation is a selective binding of the two agents, as has been shown for ACTH in the zona fasciculata (29). Perhaps angiotensin is also bound selectively in the zona glomerulosa and only with large, nonphysiologic amounts does spillage to the other zones of the adrenal occur. On the other hand, binding may be nonselective, but the enzymatic activities of the zona glomerulosa may be more responsive to the effects of angiotensin and of the zona fasciculata to ACTH. Similar selectivity could result from different levels of inactivating enzymes in the various zones of the adrenal. Another attractive hypothesis to explain this selectivity of hormone action involves the regulation of gene action. Selective alterations of messengerRNA synthesis have been shown with different hormones (30), and different concentrations of the hormone ecdysone have been found to induce chromosomal puffing in a sequential fashion (31). Thus, if the effect of these hormones involves gene action, perhaps their effect may be selective in small doses, but more generalized in larger amounts.

\section{Summary}

The effects of angiotensin, ACTH, and potassium alone and in various combinations upon the synthesis of aldosterone, corticosterone, and cortisol by slices of beef adrenal tissue have been studied.

In relatively small doses, angiotensin usually stimulated the synthesis of aldosterone to a much greater degree than that of cortisol, whereas ACTH stimulated the synthesis of cortisol without an effect upon aldosterone. Increasing concentrations of potassium stimulated the synthesis of aldosterone and corticosterone but not of cortisol. The effect of angiotensin was potentiated by amounts of ACTH and potassium that did not themselves influence steroid synthesis.

The possible mechanism by which angiotensin stimulates steroid synthesis was also investigated. Angiotensin did not affect adrenal phosphorylase activity and was potentiated by adenosine- $3^{\prime}, 5^{\prime}-$ monophosphate, suggesting that it does not act via a mechanism proposed for the action of ACTH. Evidence is presented for a site of action of angio- 
tensin relatively early in the biosynthetic pathway before the conversion of corticosterone to aldosterone.

\section{References}

1. Bartter, F. C., I. H. Mills, E. G. Biglieri, and C. Delea. Studies on the control and physiologic action of aldosterone. Recent Progr. Hormone Res. 1959, 15, 311.

2. Binnion, P. F., J. O. Davis, T. C. Brown, and M. J. Olichney. Mechanisms regulating aldosterone secretion during sodium depletion. Amer. J. Physiol. 1965, 208, 655.

3. Mulrow, P. J., W. F. Ganong, G. Cera, and A. Kuljian. The nature of the aldosterone-stimulating factor in dog kidneys. J. clin. Invest. 1962, 41, 505.

4. Blair-West, J. R., J. P. Coghlan, D. A. Denton, J. R. Goding, J. A. Munro, R. E. Peterson, and M. Wintour. Humoral stimulation of adrenal cortical secretion. J. clin. Invest. 1962, 41, 1606.

5. Slater, J. D. H., B. H. Barbour, H. H. Henderson, A. G. T. Casper, and F. C. Bartter. Physiological influence of the kidney on the secretion of aldosterone, corticosterone and cortisol by the adrenal cortex. Clin. Sci. 1965, 28, 219.

6. Kaplan, N. M., and F. C. Bartter. The effect of $\mathrm{ACTH}$, renin, angiotensin II, and various precursors on biosynthesis of aldosterone by adrenal slices. J. clin. Invest. 1962, 41, 715.

7. Kliman, B., and R. E. Peterson. Double isotope derivative assay of aldosterone in biological extracts. J. biol. Chem. 1960, 235, 1639.

8. Sutherland, E. W. Polysaccharide phosphorylase, liver in Methods in Enzymology, S. P. Colowick and N. O. Kaplan, Eds. New York, Academic Press, 1955, vol. 1, p. 215.

9. Bancroft, H. Introduction to Biostatistics. New York, Hoeber-Harper, 1962.

10. Haynes, R. C., Jr. The activation of adrenal phosphorylase by the adrenocorticotropic hormone. J. biol. Chem. 1958, 233, 1220.

11. Williams, H. E., P. L. Johnson, and J. B. Field. In vitro studies on the effect of $\mathrm{ACTH}$ in rat and bovine adrenal glands. Endocrinology 1962, 71, 293.

12. Laragh, J. H., and H. C. Stoerk. A study of the mechanism of secretion of the sodium-retaining hormone (aldosterone). J. clin. Invest. 1957, 36, 383.

13. Gross, F. Renin und Hypertensin, physiologische oder pathologisch Wirkstoffe. Klin. Wschr. 1958, 36, 693.

14. Tobian, L. Interrelationship of electrolytes, juxtaglomerular cells and hypertension. Physiol. Rev. 1960, 40, 280.

15. Liddle, G. W., L. E. Duncan, Jr., and F. C. Bartter. Dual mechanism regulating adrenocortical function in man. Amer. J. Med. 1956, 21, 380.
16. Blair-West, J. R., J. P. Coghlan, D. A. Denton, J. R. Goding, M. Wintour, and R. D. Wright. The control of aldosterone secretion. Recent Progr. Hormone Res. 1963, 19, 311.

17. Biron, P., E. Koiw, W. Nowaczynski, J. Brouillet, and J. Genest. The effects of intravenous infusions of valine- 5 angiotensin II and other pressor agents on urinary electrolytes and corticosteroids, including aldosterone. J. clin. Invest. 1961, 40, 338.

18. Ganong, W. F., and P. J. Mulrow. Role of the kidney in adrenocortical response to hemorrhage in hypophysectomized dogs. Endocrinology 1962, 70, 182.

19. Davis, J. O., C. C. J. Carpenter, C. R. Ayers, J. E. Holman, and R. C. Bahn. Evidence for secretion of an aldosterone-stimulating hormone by the kidney. J. clin. Invest. 1961, 40, 684.

20. Solyom, J., J. Sturcz, S. Kotra, and A. Salamon. Renin-angiotensin and aldosterone secretion. Lancet $1963,1,1376$.

21. Cade, J. R., and T. Perenich. Aldosterone production by rats (abstract). Clin. Res. 1964, 12, 47.

22. Marieb, N. J., and P. J. Mulrow. The response of aldosterone secretion to angiotensin in the rat. Fed. Proc. 1964, 23, 300.

23. Eilers, E. A., and R. E. Peterson. Control of aldosterone in the rat (abstract). Program of the Forty-sixth Meeting of the Endocrine Society, 1964, p. 62.

24. Davis, J. O., C. C. J. Carpenter, C. R. Ayers, and R. C. Bahn. Relation of anterior pituitary function to aldosterone and corticosterone secretion in conscious dogs. Amer. J. Physiol. 1960, 199, 212.

25. Mulrow, P. J., W. F. Ganong, and A. Boryczka. Further evidence for a role of the renin-angiotensin system in regulation of aldosterone secretion. Proc. Soc. exp. Biol. (N. Y.) 1963, 112, 7.

26. Davis, J. O., J. Urquhart, and J. T. Higgins, Jr. The effects of alterations of plasma sodium and potassium concentration on aldosterone secretion. J. clin. Invest. 1963, 42, 597.

27. Macchi, I. A., and O. Hechter. Studies of ACTH action upon perfused bovine adrenals: minimal ACTH concentration requisite for maximal glandular response. Endocrinology 1954, 55, 426.

28. Riley, G. A., and R. C. Haynes, Jr. The effect of adenosine $3^{\prime}, 5^{\prime}$-phosphate on phosphorylase activity in beef adrenal cortex. J. biol. Chem. 1963, 238, 1563.

29. Sonenberg, M., A. S. Keston, and W. L. Money. Studies with labelled anterior pituitary preparations: adrenocorticotropin. Endocrinology 1951, 48, 148.

30. Kidson, C., and K. S. Kirby. Selective alterations of mammalian messenger-RNA synthesis: evidence for differential action of hormones on gene transcription. Nature (Lond.) 1964, 203, 599.

31. Beermann, W., and U. Clever. Chromosome puffs. Sci. Amer. 1964, 210 (no. 4), 50. 